\title{
The grand challenge for frontiers in genetics: to understand past, present, and future
}

\section{David B. Allison*}

Section on Statistical Genetics, Department of Biostatistics, The University of Alabama at Birmingham, Birmingham, AL, USA

*Correspondence: dallison@uab.edu

For decades now, scientists have waxed poetically about the excitement of the fields of genetics and genomics, about the bright future ahead, about the exciting times given the advent of new technology and the rapid pace of new discoveries, and about the intense challenges facing us as we think about the ever more enormous quantities of data that stream forth from our machines. Today, things are no different. We face an ever increasing deluge of data and yet it is a welcome deluge and one of our own making. This data deluge is welcome in part because we have worked so hard and long for it, in part because it opens up many possibilities to better the world around us, in part because it offers us opportunities to better understand the world around us, and in part because it is just plain fun.

The latest waves of both data and methods to generate and understand them bring us ever increasing ability to understand our own past as a species and of that of life on our planet. And yet still many mysteries remain regarding our evolutionary history. Some of these go to the most fundamental questions about why it is advantageous for our species to reproduce sexually, to have only two sexes, to grow old and die, and to engage of certain forms of altruistic behavior (Hurst, 1996; Brooks, 2008; Nowak et al., 2010). These are some of the most fascinating questions potentially permitting some of the most beautiful and elegant mathematical and biological explanations, some of which intrigue us because they go to the fundamental essence of who and what we are and where we have come from. Thus, the first component of our grand challenge is to understand "what was," using the tools given to us by modern genomics.

The second element of our grand challenge is to understand "what is." Regardless of how we got here, how are our genomes structured? How do they work? How do they turn elements of themselves on and off in the right tissue, at the right time, to the right degree to create normal development? How does this go awry in some cases? Which genes predispose to greater agricultural yield in plants and animals, to interesting traits variations in humans and those other species we find so interesting, including and especially our domestic pets, our agricultural plants and livestock, the flowers and trees we plant for beauty, and the creatures of nature we must learn not to take for granted before they are gone (Wilson, 2002). Which genes and which variants of those genes lead to longevity, happiness, heartbreak, madness, disease, and resilience in the face of environmental challenges? These are some of the most important questions in genomic research in general and biomedical genomic research in particular. The challenge then is to find not only how our genes work in general, but how they lead to the specific circumstances we find more or less desirable in ourselves and other species. Thus, creating the richest understanding of this possible is our second challenge in understanding "what is."

The third element of our challenge is future-looking: to understand "what could be." These "what if" questions may take several forms. We may ask not only which genes or gene products do influence important phenotypes in ourselves and other species of interest, but which genes or gene products could influence such phenotypes if we manipulated them. This is the stuff of knockout mice, of transgenic plants, of selectively bred species, and of gene therapy. Here is where our ever more sophisticated molecular technology takes the fore and exposes many of us once again to the "sense of wonder" (Carson and Pratt, 1965) that drew many of us into the calling of science even as children. Another aspect of "what if" is at once fascinating in it's own right and remarkably pragmatic. It is the "what if" of the individual, the basis of personalized medicine, as well as genome based selection in agriculturally important species, and of stud selection. Here we can ask seemingly straightforward questions such as, "For this individual, what is their likelihood of producing good milk yielding offspring (in cattle), of producing drought resistant offspring in plants, or of developing colon cancer in human patients and yet we can ask even more sophisticated questions. What is the likelihood that this individual patient will be benefited or harmed by this drug, food, or poison, that has such-and-such average effect. This leads to yet more complex questions such as given the costs of treatment, the availability of preventive strategies, the predictive utility of our models, can we provide personalized recommendations to individuals? Should we tell everyone to eat the same diet, take the same preventive measures, maintain the same "healthy" bodyweight, and exercise moderately and regularly to the same degree? At present, it is difficult to know the answers. Finding them will be the third element of our tripartite challenge.

Taking on this treble challenge of "what was," "what is," and "what could be" will be much work, and it will also be considerable work for us to represent the very best of research in that area embracing the broadest views possible in this new and exciting journal, Frontiers in Genetics. And yet, as I write this, I am reminded of the German word arbeitslust. This word implies not a driven, compulsive workaholism, but rather a true passion for one's work so that it is not really work at all but rather a labor of love. We have much fun, insight, and discovery ahead of us and I look forward to working with all of you in pursuing this challenge. 


\section{REFERENCES}

Brooks, M. (2008). 13 Things That Don't Make Sense: The Most Baffling Scientific Mysteries of Our Time. New York: Doubleday.

Carson, R., and Pratt, C. (1965). The Sense of Wonder. New York: Harper and Row.

Hurst, L. D. (1996). Why are there only two sexes? Proc. R. Soc. B Biol. Sci. 263, 415-422.
Nowak, M.A., Tarnita, C.E., and Wilson. E. O. (2010). The evolution of eusociality. Nature 466, 1057-1062.

Wilson, E. O. (2002). The Future of Life. New York: Knopf.

Received: 17 December 2010; accepted: 14 January 2011; published online: 03 February 2011.

Citation: Allison DB (2011) The grand challenge for Frontiers in Genetics: to understand past, present, and future. Front. Gene. 2:2. doi: 10.3389/ fgene.2011.00002

Copyright (c) 2011 Allison. This is an open-access article subject to an exclusive license agreement between the authors and Frontiers Media SA, which permits unrestricted use, distribution, and reproduction in any medium, provided the original authors and source are credited. 